Relations industrielles

Industrial Relations

\title{
Theoretical Issues with New Actors and Emergent Modes of Labour Regulation
}

Enjeux théoriques liés aux acteurs et aux modes de régulation émergents

\section{Perspectivas teóricas respecto a los nuevos actores y a los modos emergentes de regulación laboral}

\author{
Marie-Josée Legault et Guy Bellemare
}

Volume 63, numéro 4, 2008

URI : https://id.erudit.org/iderudit/019545ar

DOI : https://doi.org/10.7202/019545ar

Aller au sommaire du numéro

Éditeur(s)

Département des relations industrielles de l'Université Laval

ISSN

0034-379X (imprimé)

1703-8138 (numérique)

Découvrir la revue

Citer cet article

Legault, M.-J. \& Bellemare, G. (2008). Theoretical Issues with New Actors and Emergent Modes of Labour Regulation. Relations industrielles / Industrial Relations, 63(4), 742-768. https://doi.org/10.7202/019545ar

\section{Résumé de l'article}

Dans le contexte d'une grande transformation de l'économie mondiale, on constate de plus en plus l'inadéquation des efforts de théorisation des relations du travail qui datent du fordisme, notamment du modèle d'analyse systémique (Dunlop, 1958) comme du modèle stratégique (Kochan, Katz et McKersie, 1986), en vertu duquel trois acteurs se partagent exclusivement la scène de l'action, c'est-à-dire les syndicats, les employeurs et l'État, dont les interactions se déroulent essentiellement dans le cadre de l'État-nation.

De ce contexte où émergent de nouveaux acteurs dont le poids n'est pas négligeable en relations du ravail, les entreprises de services technologiques aux entreprises fournissent un bon exemple, car elles sont très exposées à la concurrence internationale en concourant à la fois sur un marché du produit et du travail international. De ce fait, on y observe de nouveaux modes de régulation émergents qui, à leur tour, illustrent la nécessité d'intégrer de nouveaux acteurs et de nouveaux enjeux aux modèles théoriques du système de relations industrielles, si on veut rendre compte de sa complexité contemporaine. Pour démontrer la présence d'acteurs tout aussi importants que méconnus dans les relations du travail de ce secteur, les auteurs reprennent la définition de l'acteur en relations industrielles de Bellemare (2000) et ses conséquences sur la définition des frontières des systèmes de relations industrielles.

Une enquête a été menée auprès de 88 professionnels de l'informatique des entreprises de services technologiques aux entreprises, dans une population composée à parts égales d'hommes et de femmes. Elle a permis d'y relever des pratiques de régulation qui non seulement remettent en cause les termes traditionnels de la régulation fordiste qui, hier encore, dominaient les bureaucraties professionnelles où on employait les professionnels de l'informatique, mais encore les frontières traditionnelles du système de relations instrielles selon deux aspects. Le premier aspect concerne les trois acteurs principa de relations séparation entre les contextes du système de relations industrielles et ce système lui-même.

Les moyens du client sont nombreux, son action a une portée, une continuité ou constance, ainsi que des résultats indéniables. On ne parle plus de changements obtenus par son action, car c'est un mode d'organisation du travail entier qui émerge sous son influence. Ces résultats sont clairement liés à son action : il commande et on obéit, tant les employés que les équipes, les chefs de projet, et la direction qui approuve la teneur des contrats aux conditions posées par le client.

Ce cas, comme celui des usagers du transport en commun urbain documenté par Bellemare (2000), montre que ce qui aurait traditionnellement été considéré comme une variable exogène du contexte du système de relations industrielles doit parfois être analysé comme l'émergence de nouveaux acteurs en relations industrielles et que le système, au lieu d'être déterminé par un marché exogène est en fait pénétré de l'intérieur par celui-ci dans certaines situations. Par leur action, ces acteurs influent tan directement qu'indirectement les rapports sociaux du travail.

Ce cas illustre aussi que les rapports interentreprises sont l'un des enjeux de ces rapports sociaux. Historiquement, ces rapports interentreprises s'analysaient avec des catégories telles que les fusions, les acquisitions, les alliances stratégiques, etc. Le développement de ce que certains appellent l'entreprise post-bureaucratique ou l'entreprise en réseau semble poser en termes nouveaux la question des relation interentreprises. À titre de piste de recherche, ce mode de relation déplace l’objet des rapports de force interentreprises des formes juridiques de propriété et de contrats aux négociations des frontières sociales, ou informelles, des entreprises. Certaines, mal placées dans cette relation de pouvoir, voient envahir les frontières de leur entreprise prestataire de service, comme dans les cas étudiés ici, alors que d'autres préservent mieux les leurs. L'enjeu ici est la réduction des coûts ou une plus grande protection contre les risques de la relation contractuelle dans le cadre de produits et services peu uniformisés $a$ priori.
Tous droits réservés (C) Département des relations industrielles de l'Université Laval, 2008
Ce document est protégé par la loi sur le droit d'auteur. L'utilisation des services d’Érudit (y compris la reproduction) est assujettie à sa politique d'utilisation que vous pouvez consulter en ligne.

https://apropos.erudit.org/fr/usagers/politique-dutilisation/ 


\title{
Theoretical Issues with New Actors and Emergent Modes of Labour Regulation
}

\author{
Marie-Josée Legault \\ GuY BELLEMARE
}

\begin{abstract}
As the global economy undergoes a major transformation, the inadequacy of labour relations theories dating back to Fordism, especially the systemic analysis model (Dunlop, 1958) and the strategic model (Kochan, Katz and McKersie, 1986), in which only three actors-union, employer and State-share the stage is becoming increasingly obvious. A good example is provided by companies offering information technology services to businesses, where new means of regulation emerge and illustrate the need to incorporate new actors and new issues if we are to account for its contemporary complexity. A survey of 88 professionals has revealed regulation practices that call into question the traditional boundaries of the industrial relations system from two points of view: that of the three main actors, by bringing the customer and work teams onto the stage, and that of the distinction between the contexts and the system itself.
\end{abstract}

In view of the widespread transformations affecting the world economy (Coutu and Murray, 2005), observers are increasingly noting the inadequacy of efforts, dating back to Fordism, to theorize industrial relations, particularly the systems model (Dunlop, 1958) and the strategic model (Kochan, Katz and McKersie, 1986). These models feature only three

- Legault, M.-J., Téluq-UQAM, Montréal, legault.marie-josee@

- Bellemare, G., Département de relations industrielles, UQO, Outaouais, guy.bellemare@ uqo.ca

- The authors are members of the Center for research on social innovations (CRISES). 
actors: unions, employers, and the government, which interact primarily within the framework of the Nation-State:

[Translation] [A structurationist approach to industrial relations] allows us to recognize the potential fluidity or plasticity of institutions, particularly during times of major social transformations. In industrial relations, one could hypothesize that the Fordist (or Keynesian) crisis and the attempts to break free from these regulations in a fast-paced era of globalization, is one such episode of major transformation. That is why we think it is justified to study the boundaries between industrial relations systems or the social practices that contribute, on a small or large scale, to their systemization (Bellemare and Briand, 2006: 11).

In a context where new emergent actors are making a significant impact on industrial relations, business-to-business (B2B) technology services companies (B2BTSC) are good subjects to study regarding emergent modes of the regulation of labour because of their extensive exposure to international competition on the product and international labour markets. As part of the knowledge economy, they hire highly qualified information technology professionals. The study of work-life balance (WLB) in this segment of the labour market sheds light on the wider canvas of industrial relations and human resource management (HRM) practices in the so-called "new economy."

Given that modes of regulation are emerging from these situations, new actors and new issues should be integrated into theoretical models of industrial relations (IR) systems if their current complexities are to be explained. This article re-examines the classical identification of IR actors and illustrates its flaws with the case of the B2B sector in the Montreal Area. To demonstrate the presence of actors who are as important as they are unrecognized in the IR system of this branch of industry, we adopt Bellemare's (2000) definition of the IR actor and discuss how it impacts the definition of the boundaries of IR systems. The case study of the B2BTSC is used here as an example that supports the relevance of a wider theoretical framework in progress rather than developed. This example is used as part of a plea for a theoretical renewal and in that way of reasoning, addresses the question: are there new modes of regulation in this economic sector and if so, are there new actors besides the traditional employer - employees - state IR triangle? As we conclude so, our example supports our wider case but is not generalized at this early state; it will be added to a bank of examples that feeds the work towards theoretical renewal of IR.

\section{THE ACTOR CONCEPT IN INDUSTRIAL RELATIONS SYSTEMS}

Bellemare (2000) put forward the first analytical and operationalized definition of an actor in industrial relations. Previously, this concept had 
seemed to have an essentially accurate and sufficient definition imbedded within itself, making any analytical operationalization seem irrelevant. In both the systemic (Dunlop, 1958) and the strategic models (Kochan, Katz, and McKersie, 1986), only three actors were recognized in IR: workers and their unions, employers and their associations, and government organizations, whose function is to assist the first two actors in their relations.

However, there have been more pressing calls since the mid-1990s for a broader concept of the IR actor, especially one that would reflect social movements; thus, Collins (2006), Piore (1995) and Dabscheck (1994) appealed for inclusion of interest groups such as women, the disabled, ethnic minorities, homosexuals, and others into the study of IR. Practitioners in the field, whether unions or employers' associations, had long been striving to take these groups into account (Briskin, 2006) and did not wait for the renewal of the theoretical models to include them. Since the 2000s, authors such as Kochan (2000), Hyman (2004), Edwards (2005) and the ones gathered in the BJIR (2006), have promoted the inclusion of the study of the relations of IR system actors with local communities and national and international social movements, which in our view means that it is necessary to take into account the fluctuating boundaries of IR systems instead of promoting static analytical models. In Québec, there have been cases of intra-union interest groups fighting for equity and for the respect of fundamental labour rights in relation to gender or age in collective agreements negotiated by their unions (Brunelle, 2002; Legault, 2005a). In the North American tradition of industrial relations, the main way to approach this kind of situation was through the intra-party attitudinal structuration in the theory of collective bargaining (for example, Walton and McKersie, 1995). Yet, in the latter cases, we have to account for the fact that some groups in a unionized context rely on the support of extraunion organizations (in these cases, feminist and human rights groups) to defend their cause at work, bringing non-union actors into the field and, moreover, bringing judicial authorities other than labour judicial bodies into the field. More than a problem in aggregating members' interests, we face a new step in the defence of rights at work, where unionized workers look beyond their union to defend their interests at work and against these same unions. These actions and actors come to have a direct effect in the working conditions in these unionized contexts, and this, not only without but despite the local union's action.

After studying Quebec public transit user groups from 1975 to 2000, Bellemare (2000) demonstrated that these groups were actors in this IR system. Through persistent action, they exerted a durable influence on a new concept and production of public transit service, even becoming actors 
in the co-production, co-design, and co-surveillance of service and work relationships and in the adoption of new labour laws. Using his empirical study, Bellemare proposed a structurationist definition of the actor as the foundation for an operationalized analytical framework of IR action. The concept of IR means the set of actors, rules, institutions, and subjects of the social relations of production in modernity and late modernity; these elements are defined in the following section. Action is the ability to modify one's environment and to intentionally or unintentionally produce consequences through one's behaviour (Bellemare, 2000: 385). Bellemare thus defined the IR system actor as an individual, group, or institution with the ability to influence, through its action, the direction of IR (direct action) or the actions of other IR actors (indirect action; Bellemare, 2000: 386). For example, unions do not have the power to legislate labour matters but they can influence the State through lobbying and get government to take action on their demands. In the resulting model (Figure 1), an actor not only must act in order to be recognized as an actor, but he must also have the ability to get other actors to take his aspirations into consideration and to respond favourably to some of them.

FIGURE 1

Flexible Actor Model of Industrial Relations

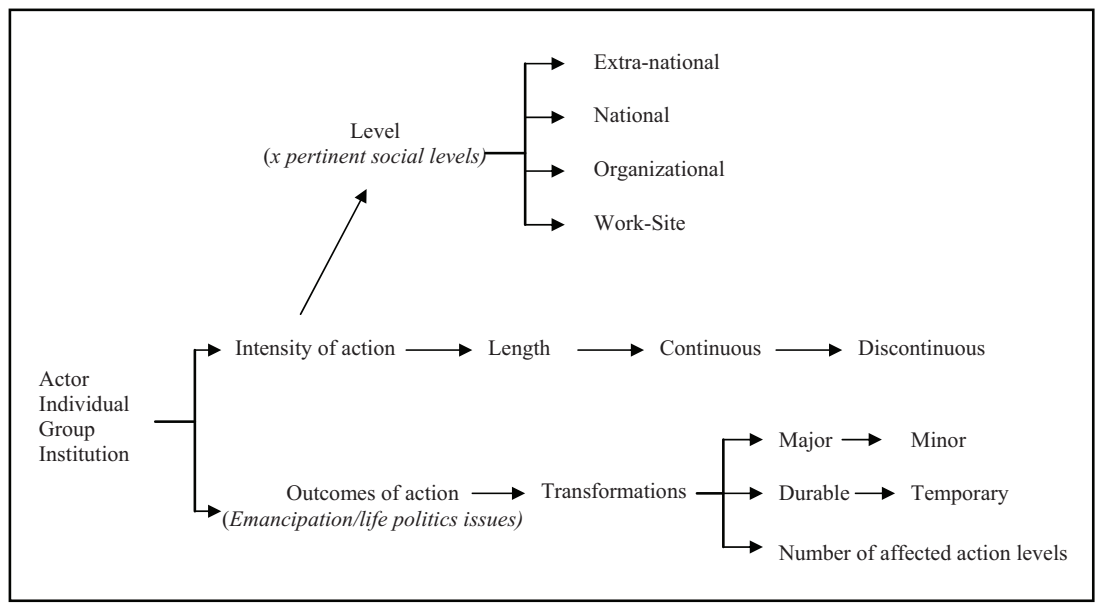

In the new analytical framework proposed, the traditional dichotomy between actors and non-actors in industrial relations is set aside in favour of the influence continuum resulting from the actions of individuals, groups, and institutions whose importance as IR actors varies in time and space. In the classical approaches, individuals and sub-groups of unions, for example, were not considered actors. 
Actors in a given IR system assume their role in multiple ways in an organization's or a sector's internal social relations as they influence the organization of work, the management of human resources, and the determination of working conditions. In various IR system dimensions, their action can vary in intensity (occasional or continuous), scope (limited to the organization or extended to include regulatory institutions), or outcome (lead to or impose large-scale durable transformation or remain circumscribed and prompt minor changes). This definition of actor has had productive applications in various national and international IR contexts; ${ }^{1}$ its explanatory power is not limited to the B2BTSC sector, of course. We here limit the study to this particular empirical case.

In our study, clients and project teams in B2BTSC are IR actors, if, by their action, they can directly or indirectly influence the direction of IR or HR policy or the actions of other IR actors. We will show that they act on an intra-enterprise and inter-enterprise basis (work-site, organizational), on all aspects of the work relations (co-production, co-conception and co-surveillance), with a continuous action that has major and durable impact on the working conditions of these workers

Three specific details must be added to this definition. First, as Abbot (2006) has shown, when he has used Bellemare' framework, it is not fully essential for the actor to have an action at all levels and at every moment to exert an impact on the definition of work conditions or of frontiers of the IR system.

Second, this definition of actor, grounded in the structuration theory of Giddens (1984), itself grounded in the critical realist epistemology of Bhaskar (1975, see Edwards, 2005), poses that the definition of who is and is not an IR actor is context sensitive or space-time sensitive: one can be an actor in a particular case and not in another case. For example, Bellemare (2000) has identified the user groups in the case of the Montreal city transit system as actors between 1975 and 2000, but this was probably not the case in the Gatineau transit system at the same period. It is the conceptual and analytical definition that has a good generalization potential, not the empirical new actors that can be identified with it.

1. This concept was used by Bellemare and Ackéyi (1999) in their analysis of the role of actors such as the World Bank and the International Monetary Fund in Gabon, and was afterward applied to an organization of miners' wives in Australia (Jones, 2002), and to European Union experts in the implementation of national industrial relations policy (Baldacchino, 2001). It was used by Michelson (2006) in relation to the role of chaplains in Australian businesses, by Bell (2006) on the same topic in England, by Abbott (2006) in relation to the role of citizen advisory boards that advise non-unionized employees on problems in the workplace, and by Peltonen (2006) in relation to the status of the multinational in the industrial relations system. 
Third, in this definition of the actor, the traditional IR actors: union, employers and state agencies, because they are the most directly involved in the work relation will undoubtedly always be identified as actors. The most relevant question in this case becomes to what extent do they have an impact on the particular IR system in which they intervene? The answer is more empirical-analytical than based on an a priori basis. For example, it is probable that the soviet unions in the 1960's were IR actors in Russia, but did they have the same type of impact that Canadian unions had at the same time, considering that the Russian unions were subservient to the communist party?

The IR system model proposed by Jones and Bellemare (2005) considerably expands upon the concept of the outcomes of the IR system (Figure 1, in italics). In traditional models, they are summed up by collective agreements, organizational performance, and by the number of strikes and grievances. In the new model, new and old actors are given the power to produce results in the form of new modes of regulation and new social relations parties.

\section{THE SHIFTING BOUNDARIES OF THE IR SYSTEM}

Beginning in the 1940s, IR theories essentially adopted a Fordist perspective as they designed the employment relationship around the control of wage earners by contracts of undetermined length, and legal subordination. The form of the firm is changing, however, into a postbureaucracy, post-Taylorist, network-firm (Briand and Bellemare, 2005, 2006; Legault, 2005b). New forms are giving rise to a multitude of employee statuses. The organizational entity relevant to IR is not necessarily the legal organization-employer structure. An entire stream of research is developing around the view of the firm's boundaries as being porous and movable and the consequences arising from these conditions for management and HRM practices, such as boundaryless careers (Arthur and Rousseau, 1996; Fleming and Spicer, 2004; Heracleous, 2004).

In this study, the actions of clients and project teams as IR actors are observed as they relate to the organization of work and the institution (political decision making in the organization). From the sociology of work we learn that the distribution of work requires coordination and is possible only if the organization of work is conceived, executed and, of course, supervised. However, these tasks have assumed new forms that emerged since Taylorism. The study of these two groups will show how they fulfill the role of co-producers, co-supervisors, and co-designers of the service and therefore become major players in this particular IR system. 
The concept of co-production suggests that the action of a goods or service user intentionally or unintentionally influences the manner, effectiveness, and outcome of a service. Actors to various degrees may seek this co-production and be more or less controlled while doing so. The user or client is a co-producer in the service sector, to degrees that vary according to the service's level of sophistication. In the restaurant industry, for example, this stakeholder acts less efficiently than in the consulting industry.

Similarly, the receiver of the service may be a co-supervisor of the work (while at times being supervised himself), both in an individual capacity (by making complaints, for example) and as part of a group, by participating in pressure groups or setting up and implementing various supervisory specifications internally (grievance committees, user committees, board of directors) and externally (creating a system to gather user complaints, or users obtaining legal recourse before the courts).

Lastly, the receiver of the service may be a co-designer of that product or service and could thus interfere with the standards and prescriptions of the company's management by requesting another product or delivery method. For example, the receivers may be invited individually, collectively, during discussion groups, or as representatives of user groups to help define their needs and the products and production methods, and to evaluate the quality of products or services. The more the service is complex, the need imprecise, and the anticipated result unforeseen, the more the receiver's involvement is requested. Receivers may also volunteer their own participation, and lobby individually or collectively for a greater role as co-developers of a product. This is what the feminist movement did in the health sector in the 1970s, at a time when women decided to no longer allow the mostly male medical profession to dictate their needs and the type of care for their situation. Similarly, public transit user groups have made similar demands.

\section{METHOD}

We used the following sample of five organizations of the new economy and two traditional large bureaucracies to make our comparisons:

- Three small B2BTS businesses (IT-1, IT-2, and IT-3);

- Two businesses that develop optics and telecommunications products (Optics I and Optics 2);

- Two bureaucracies:

- The IT department of an insurance company (Insurance-I),

- The IT department of a real estate management company (Real Estate). 
The organizations in the first group had between 100 and 150 employees, while those in the second group had between 500 and 1,000. None of the employees in any of the groups were unionized. Data were collected on a wide range of topics regarding story of the organization, HR policies in general and towards WLB in particular, work content of individuals and detailed work organization, including lengthy accounts of project management.

For most of their activities, all the organizations keep a constant flow of communication with clients and use the management by project method. In keeping with widespread current trends, the IT departments in the two bureaucracies had been organized into independent centres providing service to the entire organization, with instructions to deliver service with optimal returns. As such, they competed with external firms and were in danger of being abolished if their competitors were cheaper and management used their services instead. Although the bureaucracies' IT departments were studied for comparative purposes, they organized work in the same manner even though they operated in different organizational contexts.

A total of 88 respondents participated in the survey (43 men and 45 women) between January 2001 and April 2002. In each organization, we interviewed one or two human resource managers, two to four immediate supervisors (project managers, team managers) - usually a man and a woman-and 10 to 12 employees (equal numbers of men and women) working in computer or software engineering, often as qualified engineers but not always, the recruiting strategies varying much and being part of the clue in these organizations. The in-depth interviews lasted one and a half to two hours, and the interview guide was semi-structured. Documentary information regarding the seven sites was collected as well. Many questions were asked as standard procedure to everyone, so simple descriptive statistics can be summed up, though the study was qualitative. Data were analyzed with the grounded theory procedure and NVIVO software program. Only part of the categories, relevant to our question, will be accounted for here; many other publications quoted here account for the rest of the study.

\section{ALTERNATIVE SOURCES OF WORKPLACE REGULATION}

Based on our observations of the B2BTS firms in our study, we suggest that the client and the peer team helped establish the production framework in the organization, and, in many ways, became a substitute for the human resources department.

\section{Project Management as a Form of Work Organization}

The five SMEs dealt with numerous external clients. The clients of the two bureaucracies' IT departments were the departments of the same firm, 
and all of them used a common work organization method that can be briefly described as follows. Each project was a binding contract under which the supplier-organization usually provided the client-firm with a deliverable (computer product such as software) and also a service (technical support, maintenance, customer service). To produce the good, a team was built around a project manager. These teams were multifunctional, relatively autonomous, temporary, and constituted according to the client's needs (Alvesson, 1995; DeFillippi, 2003, Legault, 2004). Although short-lived, the teams had to produce goods or services to be delivered on a date and at prices established by a succession of contracts with several clients. At the term of each project, the team was dissolved and the professionals thus freed up were drafted into another team to work on new pending projects.

In a post-Fordist context, these much sought-after professionals have careers that are called boundaryless; that is to say that these careers are characterized by frequent short term contracts for different employers, instead of a stable employment relation (Arthur and Rousseau, 1996). They are very mobile on the job market, which itself strongly encourages their mobility. The concept of employee loyalty, long held as a major indicator of employee commitment, is replaced in this industry by a desire to agree to anything to satisfy a client within the scope of a project. The commitment thus expected is intense, but not necessarily long term. Neither the professional nor the employer views a long employment relationship as a priority (Legault, 2004; Singh and Vinnicombe, 2000).

The professionals interviewed in the WLB research were assigned to the production of services but rarely involved in the negotiation of contracts in which budgets and deadlines are set, even though they were the ones to comply to the extent possible with its conditions. Yet budget conditions and deadlines are the key issues in risk: if too restrictive, they could lead to the failure of the project, and the professionals and the project managers hold the primary responsibility for the project's success or failure. Therefore, the pressure should have been greater in the five SMEs (which have external clients) than in the two bureaucracies, but that is not the case: at Insurance-I, whose clients were other departments in the same firm, pressure came from within because the department had become an independent for-profit centre. At Real Estate, the requirements of clients and the pervasive possibility that they might go with a competitor exposed the professionals to the same type of pressure that is found in other project management scenarios.

We can already see that this situation sets the client in a key position to establish the framework for certain —highly important—working conditions, as the client draws up budget and deadlines in a context of fierce competition that spares him/her a large freedom of maneuver. And yet, this in return 
determines how many people the firm can assign to the project and the working schedules.

\section{Human Resources Departments, a Background Presence}

The clients did not limit their influence to occasional marginal transformations of existing industrial relations practices but actually established the organization's framework for in-house production and wielded numerous decision-making powers that in other environments are normally assigned to the human resources (HR) department. In three out of the five SMEs in our sample, the HR department had been created shortly before our visit. As well, in the firms that had a more structured human resources department (two SMEs and the two bureaucracies), the department was not involved in the employee-project manager relationship (Legault, 2004).

The HR department played a negligible role in the decisions that normally are within their mandate elsewhere, in hiring matters as well as in issues of vacations, holidays and schedules. The following extracts are particularly eloquent:

[Translation] Well, some of them... when someone leaves the team, it's usually not [the employer's] decision. (Oh, to that extent?) Yeah, he [the client] has the last word. The client decides who gets on the team and who goes: "I'm not happy with him, he has to go." "Yeah, but wait, let's talk to him first." ... Then it happened that he decided: "That guy goes! We don't want him anymore. That's final; he's rude on the phone..." so they said, "No, we don't want him anymore." So then they [the department] warn him ahead of time: "So in one month, you're gone, you're, like, going to another project and you're leaving that team, it's because of the client." (CGF-1-18-27-8-01-19-3)

Because in our field, the client makes the decisions about a lot of people. For example, when we want a vacation, "Alright, but... we have to check to see if it's o.k. with the client." (MF-3-22-28-3-01-19-3).

When assigned to establish working conditions such as the professionals' hours, work schedules, or telecommuting, the project manager made highly variable decisions, essentially based on the client's wishes.

In these situations, the principal functions of the HR department were to:

- Ensure that the firm complies with the main public labour laws;

- Manage the application of its benefits (pensions, if applicable, vacations and holidays, and so forth);

- Provide the other departments with the workers needed for their operations;

- Apply sanctions and execute lay-offs or dismissals upon request. 
In this particular context, far from witnessing anomie we see the emergence of new sources of regulation taking the place of Fordist regulations in the bureaucratic environment (collective agreements, internal regulations and procedures, and labour laws). Among others, the client and the peer team emerge as major actors. At the heart of all the management decisions of the organizations under study, and in all matters, particularly HR, WLB, work organization, and telecommuting (Legault and Chasserio, 2003), were the clients' imperatives (tight contract deadlines, pressing need for the product), followed by the concerns of the team, whose second imperative, loyalty, was subordinated to the client's needs (each worker had particular skills and had to be present in case he was needed, under peril of delaying product delivery).

Here we can see that the client is no longer outside, talking the managers into his/her liabilities, but in fact, inside the firm, managing the project's staff in many daily decisions, getting the project manager into relaying his/ her decisions. At the work-site level, (s)he is continuously involved (high intensity of action, see figure 1) and entails major transformations in the internal politics of HRM, as we will see, in a durable way.

\section{CLIENTS AND TEAMS AS CO-PRODUCERS} AND CO-DESIGNERS OF THE GOOD/SERVICE

\section{Clients: Spectators No Longer}

These two roles are examined in the same section because the conception and production of a good or service by technology firms are so tightly intertwined in B2BTS firms that it would be redundant to separate these functions for analytical purposes, as was done in Bellemare's (2000) study of public transit users.

Unlike plant workers, these B2BTS professionals interact constantly with clients because the products requested are sophisticated, customized, and complex to make. The client becomes involved to ensure that the product is adaptable to the type of data to be processed, to the information system currently in place at the client's business, and to its users, and so forth. Moreover, the order changes constantly as the development cycle goes on. Regardless of the content of the initial contract, the client withdraws or adds details to the order during product development when informed by the developer of limits and constraints that challenge the initial order, and also of possibilities of which he had been previously unaware. This situation excludes any rigid operational planning from the outset, and forces developers to make accommodations for the conflict between the contract's budget and deadline requirements on the one hand, and the 
client's constantly evolving demands, additions, and quality expectations on the other.

As the producers were qualified to hold productive discussions with the client because of their hermetic knowledge and the specialized nature of the order, management transferred the role of transacting with the client during production to them. A major part of their work involved diplomacy (Legault, 2005b). The project managers were not the client's exclusive contact, and the professionals were often called upon to work at the client's temporarily.

Professionals must take into account the client's requirements from the outset of product development, and keep up with changes in these requirements and in production deadlines, produce and deliver the finished good to the client within the set time, and then provide post-production service. The producer has scant bona fide powers of negotiation because contracts are made in a highly competitive market that gives clients the lion's share of the power (Anderson-Gough, Grey and Robson, 2000).

Thus the members of a team responsible for implementing software in three months, for example, had to resolve these conflicts on a daily basis and make logistical decisions that invariably had a determinant impact on the project's success or failure. For instance, they had to consider whether it was better to sacrifice one test phase in order to adhere to a deadline and thus risk producing a product with bugs, or else put quality first by taking their time and risk testing the client's patience before product delivery (BerrebiHoffmann, 2002) In the face of such sizeable risks, the optimal solution was often to attempt to do it all, which resulted in unlimited overtime and a tremendous amount of commitment from the employees. To adhere to the established price, it was necessary to lower production costs, of which the main element was manpower. Thus unlimited work hours without compensation for overtime became a major asset.

The client did not limit his contribution to the effectiveness of the service simply by being compliant or influencing the production process by sharing his concerns with management, but was placed at the very heart of the production process. Clients were active at every phase, negotiating each step with the producer. For their part, the producers had to keep the clients informed of obstacles and/or new possibilities that occur during production. It was the client's specific orders, rather than a product offer determined by a group of managers, that triggered the beginning of the production process. The resulting operations did nothing but reinforce the influence of the client, who led the service supplier rather than subordinate himself to him. The client and the professional were not on an equal footing in terms of competencies, but the competitive market confers an undeniable edge on the party that requests the service. 
Let's make it clear here that the professionals are still salaried employees of their firms, in all seven sites; this strong influence of the client doesn't appear anywhere in the juridical structure and remains informal, though very powerful due to two important factors: fierce competition and a close supervising relation with the professionals. This influence is not buffered by the management; on the contrary, the responsibility for the client's satisfaction in all his/her requirements is conveyed to the professional, whose assessment will rest mostly on that same satisfaction.

Here we can see client and professionals in a strong working relationship, because of their direct negotiating relationship and, mostly, because of the direct influence of client requirements on the production process. This, in turn, has a direct influence on working conditions, that is to say working time in this particular case, as we will see. This is a major and durable outcome of the continuous client action on working conditions at work-site level (see figure 1).

\section{Disapproval of Shorter Work Schedules}

In these B2BTSC, where there is hardly any formalized HRM, there are few policies or official rules for scheduling or for workplace organization. In all the companies visited, only one had a work time policy, and its application was left to the discretion of the project manager and the client. Shorter work schedules were usually denied, particularly in the case of part-time work and telecommuting arrangements (Legault and Chasserio, 2003).

Shorter work hours were often frowned upon. One of the female project managers we interviewed shared this:

[Translation] When I have people on a four-day workweek, I think they're not ambitious $[\ldots]$ !...] We have so much work, we push our people, the projects aren't easy, you know... Yet there are people who work four days a week... like the saying goes, it's a bad fit [...] The company does offer it, I'm happy for those people, but on the other hand, you look at them and you might not feel like having them on your team. When you have a really urgent project... (ASF-3-3-11-7-01-19-3)

In short, the obstacles to work organization that lead to the denial of part-time hours and that were usually invoked to justify the need to agree to overtime are the client's needs, the needs of the work team, the interaction that was required among team members, and the importance of each member's unique qualifications to a highly specialized and skilled production process. The obstacles that were expressed could be understood only in light of the contrast between the volume of work and the human and financial resources needed to execute the contracts (Legault and Chasserio, 
2003). Both management and employees (not equally, since the men agreed with the needs more than the women did) mentioned these requirements as the basis for their disapproval of reduced working hours.

These qualified technology workers reported more often to the client and to their own teams and were more often subject to their authority than to that of their own project manager. Our respondents' highest priority was their own reputation; therefore, they were likely to give the client the required flexibility and availability. Reputation is built, approved, and changed by the drafting decisions of project managers and clients, and it is the number one placement asset in a highly mobile job market (Berrebi-Hoffmann, 2002, Courpasson, 2000). The regulatory framework extends to the entire draft pool in which each professional covets a place. As the professionals are highly mobile, the client's action level is not just organizational; it's also local, if not national.

The main argument against shorter hours that was freely given was that clients do not have part-time needs but rather continuous requirements:

[Translation] It's part of the game. Yeah. Yeah. A consultant who does 9 to 5, I'm convinced that he won't be a consultant for long. Because there are all types of situations that require our availability...There can be a last-minute situation that makes it necessary to, well, you know...I'll give you an example; in my division we had a product to make in two days, so there was a chance we had to work both nights until midnight to be able to deliver. So that's a lot...You have to be flexible in these cases. Yeah. (CGSH-10-4-12-10-01-19-3)

Again in this case, the client dictated to the project manager how working hours should be managed, for example, by refusing to work with professionals on the team who requested shorter hours. For its part, management dictated work hours by leaving the implementation of scheduling and overtime compensation policies to the discretion of the project managers, who are first and foremost dedicated to the client.

In short, what we see here is a client directly conveying his/her orders regarding work time to the project manager or directly to the professional, in absence of any intervention coming from the HR department, even when the firm has some policies regarding part-time work or overtime billing. The client can directly transform HR local policies on working time in a major (calling off their application) and durable way (in many projects throughout time; see figure 1).

\section{The Regulatory Role of the Project Team in the Co-Design Production Phase}

Shorter work hours and work organization also collided with a second consideration: the team itself. The work could not progress unless team 
members were constantly interacting. No one was afraid to say: "When one team member is missing, the work of the rest of the team is delayed," or that a part-time schedule was unsuitable for managers or professionals, who have unique qualifications and might be needed at any given moment.

In the same vein, in denying the opportunity to telecommute, team managers offered that the frequent exchanges among team members were a priority that required everyone's co-presence, and that the unique skills of team members meant that someone's absence could delay the whole team. Naturally, the client's requirements concerning the presence and availability of the employees on their project underpinned all these comments, either because the team members provided customer support, the client wanted to be able to talk to them at any time, or the employee worked at the client's during the duration of the project and the client wanted him to be present.

On this subject, a female manager at IT-3 said:

The employees won't draw up their schedules without taking the others' into consideration, and they also have to get the project leader's agreement. (DDF7-7-6-3-01-19-3)

The group that supplied the unlimited effort expected would not approve any exceptions for a team member because the rest of the group would have to make additional efforts to compensate for their absence, and the performance of the team is evaluated as a whole. On the other hand, a worker who saw that his freedoms had negative consequences for the client or that they burdened his co-workers would not impose such compromises on his work environment. The social sanctions of team members are to be feared because these colleagues have the power to make recommendations to future clients and therefore to influence a professional's reputation. To preserve reputation, the professional imposed all compromises upon the family (Legault and Chasserio, 2003).

We can only observe that the team is collectively driven by the client's imperatives in the same way professionals are; moreover, small arrangements among professionals in a team are hindered by the pressure imposed on them as a group.

\section{THE CLIENT AS HUMAN RESOURCES CO-SUPERVISOR}

\section{Vanishing Control and Double-Edged Autonomy}

Although ostensibly autonomous within their firms, these employees had lost most of their control over the way they organize work. Given that the HR department does not intervene in the relationships between project 
managers and employees and gave the former a great deal of latitude (Chasserio and Legault, 2005), the client is unchecked in his dealings with project managers and the professionals because his role is not described in the official organization chart and the challenge of satisfying the client is part of a consensus that is not formally monitored. Reputation becomes a driving force of self-discipline. Indeed, in respondents' own terms, boundaryless careers and management by project turn workers into "consultants" (according to their own terms) within the organization that employs them. Indeed, many respondents, still salaried employees at their employer's, had a consultant status at the client's that "borrows" them through a service contract agreement (while being bound to their own employer by an employment contract) for the duration of the project. Whether dispatched to the clients' or working at their own employer's, the workers interacted constantly with the client, in contrast to suppliers of manufactured goods in an industrial setting, for instance.

Within our sample, autonomy was viewed equally as a prized working condition and a work requirement that came with heavy responsibility. Seventy-six respondents $(76 \%)$ said that they were autonomous in their work, i.e., in the way they organized their tasks and carried out projects, but also said that the project manager monitored compliance with deadlines and budgets. Only $9 \%$ said they had very little autonomy. The professionals also had a great deal of operational autonomy in deciding how to make the product, in their interaction with the client, and in the organization of their work, a condition they value because it allows them to express their creativity. When asked what their employer considered the most important quality of an ideal employee and which asset was required of them, autonomy was number one on the list.

Autonomy is not only a bestowed advantage but also a requirement of the profession that carries heavy obligations and is received in exchange for a commitment to satisfy the client. As projects frequently overlap, employees juggle heavy parallel demands and establish the order of priorities themselves in the case of conflicting tasks, while possibly facing reprimands for the decisions they make. Instructions such as "Do whatever it takes to meet this deadline", or "Here's the objective, make sure you meet it" are inputs into autonomous decision making that foster more stress than professional satisfaction (Legault and Belarbi-Basbous, 2006). When faced with a problem, our respondents quickly realized that they could always be held accountable because of the latitude they were given to establish operational methods and priorities.

The quest for customer satisfaction is a powerful instrument of control as it is the main issue in the crucial evaluation process (Anderson-Gough, Grey and Robson, 2000; Courpasson, 2000; Legault and Chasserio, 2003). 
One observes a noticeable-and inexpensive-regulating effect in the constant internal competition among professionals, either among project managers or the members of their team, who were seeking for a good position in the next drafting process within their own firm or in another firm in the short or medium term, or a position as project manager or else simply the maintenance of their own reputation. We must notice that autonomy is, in fact, a way to convey to the professionals the responsibility of negotiating with the client and to make them entrepreneurs eager to build their reputation. In the process, clients' needs are prevailing as first determinants of clients' satisfaction and conditions of work as well.

We must notice here that neither the project manager nor the HRM department has any supervising role; self-censorship of the professional can be relied upon, as they are in an entrepreneurial relationship with the client, eager to have him/her satisfied in order to keep a spotless portfolio.

\section{The Client and the Organization of Work: Long Hours and Overtime Management}

In most of the organizations visited, there was no provision governing the professionals' compensation for overtime. Sometimes overtime was paid at the same rate as regular work, or the employee was given time off equivalent to the rate of his normal pay, or equivalent to time and a half or double time. In other cases, overtime was unpaid and the employee was not given time off. The many hours of overtime that professionals did were rarely, if ever, paid (Legault and Chasserio, 2003). While not a universal practice, it was nevertheless a widespread policy to withhold compensation for overtime except in the case of hourly workers and to consider the compensation of professionals, which is calculated at an annual rate, as a lump sum that is not tied to a specific number of work hours, despite the fact that professionals often put in long overtime hours.

It was the project manager's responsibility to estimate the number of vacation hours to offer as compensation for overtime, but overtime was not necessarily accounted for in an official document. The granting of time off for working overtime depended on an informal agreement with the current project manager and could be compromised at any time, depending on the client's needs, particularly in relation to budgets and deadlines. The project manager determined the threshold that had to be reached before offering compensation for accumulated overtime. It was reported that IT-1 issued a moratorium on paying overtime rates. This was justified by budget cuts and the fact that "the client no longer wished it."

In the organizations we studied, the official work week ranged from 35 hours (Real Estate and IT-3), to 37.5 hours (Insurance-I, IT-2, and 
Optics-2) or 40 hours (Optics-1 and IT-1). The following table describes the distribution of the real hours that respondents consistently, not occasionally, put in throughout the year. ${ }^{2}$

TABLE 1

Real Work Hours by Gender

\begin{tabular}{lcc}
\hline \multicolumn{1}{c}{ Hours worked per week } & Women $(n=45)$ & Men $(n=43)$ \\
\hline Adherence to the hours stipulated in the work contract & $18(40 \%)$ & $7(16.3 \%)$ \\
35- to 39-hour work week including overtime & $6(13 \%)$ & \\
40- to 49-hour work week including overtime & $18(40 \%)$ & $26(60 \%)$ \\
50- to 59-hour work week including overtime & $3(6.6 \%)$ & $9(21 \%)$ \\
60+ hour work week including overtime & 0 & 1 \\
\hline
\end{tabular}

Long work hours are characteristic of work organization in the B2BTS industry (Hellens, Nielsen and Trauth, 2001) and of the knowledge economy (Alvesson, 2000; Bailyn, 1993; Evetts, 1998; Perlow, 1999; Simpson, 1998; Singh and Vinnicombe, 2000). Work hours are one of the factors for measuring employee commitment in this sector, which in turn is a major factor in determining who receives a promotion. Employees are judged on their "presenteeism," or the many overtime hours they willingly agree to do (Bailyn, 1993: 79).

To illustrate, here is a quote from a project leader with Insurance-I who very clearly articulated the commitment she expected from her employees:

[Translation] I expect an employee to give his all...in terms of productivity. Yes, he can enjoy his work and continue to learn ... [...] even find personal satisfaction in it, but he should give his best. After all, we're professionals, we're well paid, so I expect that those people, when they're at work, give the most they can. (ASF-3-3-11-7-01-19-3)

The employees were encouraged to give the "necessary time" rather than a fixed number of hours to their work.

We must not see this autonomy in assessing what the "necessary time" is as the freedom to determine it; in this assessing process, the clients' needs are prevailing and the respondents' discourse on this topic is obvious. In all this, the client's action is continuous, major (as in turning down an overtime compensation policy) and durable, not an exception.

2. There were wide gaps between the men and the women, which are discussed elsewhere (Chasserio and Legault, 2005). 


\section{CLIENT AND TEAM AS ACTORS OF REGULATION}

\section{Entrepreneurial Discourse and Consensus Perception}

The customer service attitude expressed as entrepreneurial discourse was evident in the respondents' remarks, despite the fact that they were salaried workers. For example, when asked about how they viewed work and success, their priorities were customer satisfaction, being useful and solving the customer's problems, and respecting the deadlines and the agreed-upon budget. Other dimensions of professional success were secondary, such as job satisfaction, continuous learning, and satisfying the boss's requirements. Thus, the concept of commitment among professionals had shifted substantially from loyalty to one's employer to temporary but total loyalty to the client (Anderson-Gough, Grey and Robson, 2000; Singh and Vinnicombe, 2000).

Did this make the client and the team actors in the industrial relations system? Yes it did, at least from one significant standpoint. These actors did no less than relieve the employer of his regulatory role and unburden him from the inevitable tensions created by the conflicting interests of capital and work, the effect of which was to make these work environments high-consensus organizations. The professionals asserted that individual performance ensured the organization's competitive position on the market, and consequently, the client's satisfaction secured their own jobs (Singh and Vinnicombe, 2000). They integrated this constraint so thoroughly that their perception could be equated with a shared interest with the leadership of their organization. Bending to the clients' very high demands is due to globalization and generates stress that respondents viewed as resulting from the client's power, not the employer's:

[Translation] Yes, we evaluate all the tasks to be done, the schedule for doing them (...). In $90 \%$ of cases, the client wants it done in half the time. So we end up sort of compressing the length of time that would have been more ideal. So our people who manage projects feel the stress because they're handed a project that doesn't give them much latitude with the deadlines. (DSF-13-123-8-01-19-3)

Among salaried workers, this situation can only be explained by the mobility of experts in a post-Fordist salaried work market where loyalty to one employer no longer makes sense. The professional considers himself/ herself all the more autonomous because the demand is constant. The organization is just one of the places where professionals belong, and they have multiple loyalties, including to their clients (Alvesson, 2000; Robertson and Swan, 2003). In this context, boundaryless careers are an additional factor in the production and reproduction of the mode of regulation of the 
work begun under the client's control. However, boundaryless careers establish themselves within a labour-regulating framework in which power relations are asymmetrical.

\section{Levels and Modes of Labour Regulation}

At this stage, the client's action had a determinant effect, either directly, for example by demanding that a particular worker be assigned to or released from a project, or when evaluating individuals, the project manager or the team, and so forth, or indirectly, by co-constructing the product or service with the requirement that the sub-contracted company adapt to his own deadlines and schedules, and so forth. This direct action is far different from the indirect client's action on the manufacturing organization, for instance; in that latter case, the client has an indirect action in deciding to patronize or not, at most negotiating prizes.

The team, for its part, required the co-presence of all its members and a uniform level of contribution to the collective effort. While the sociology of work has often documented the regulatory role of the work group to counter the mounting requirements of management (Bendix, 1974; Reynaud, 1988; Sayles, 1958), we find the opposite situation here because the work team helped intensify the work, whether it was paid or not. For salaried workers, their job was on the line in the medium term. The team, just as much as the project manager, was capable of marginalizing a professional, of keeping him from participating in projects that might be gratifying in terms of money, learning, and reputation, and, most of all, of reducing his employability by tarnishing his reputation.

For the professional, the boundaries of the firm he works for are a limited regulatory framework on two fronts. First, the current client is a major actor of this regulation, so the regulation space far exceeds the legal boundaries of the direct company/employer. This regulation takes precedence over the national legal framework, which is loosely followed (additional hours can be refused under section 59.0.1 of the Act respecting labour standards, but this provision has no effect in this environment. A salaried worker may well refuse to work, but his reputation would be tarnished. The same holds true for parental leave or personal leave for family matters, and so forth). Second, reputation is at the heart of the sectorbased regulation of professional work in this industry. It is the object of a co-construction among the actors involved in the project over the short term, and among the actors of the sector, at least regionally, over the medium term. To build a reputation (or to lose it), one must, in fact, work or have worked on more than one project and for more than one client. Therefore, each of the worker's decisions feeds into this company/short-term and 
sector-based/long-term co-construction of the regulation of labour, and these two time-space contexts of labour regulation are articulated or interrelated at local as well as international level (see figure 1).

\section{CONCLUSION}

A study of a fairly evenly distributed (by gender) sample of 88 professionals in B2BTSC companies identified the regulatory practices that call into question not only the traditional terms of Fordist regulation, which until very recently dominated bureaucracies that employ B2BTS professionals, but also the traditional boundaries of the IR system from two perspectives: that of the three principal actors-the employers, the workers and the State-through the addition of clients and work teams, and the separation of the IR system's contexts from the IR system itself.

The clients had various means at their disposal, and their actions had undeniable scope, continuity, as well as undeniable results. There was no longer the question of changes brought about by the clients' action because the clients' influence actually gave rise to an all-encompassing method of organizing work. Clearly, this outcome was related to the client's actionhis commands were given and they were obeyed by the employees, the teams, the project leaders, and management, which approved the contract's stipulations in response to conditions the client imposed.

This particular case, as that of the public transit users documented by Bellemare (2000), shows that what may be traditionally considered a contextual dimension of the IR system must sometimes be analyzed as the emergence of new actors in IR. Through their action, these actors influenced the social relations of work directly as well as indirectly.

This case also shows that inter-organizational relations are one of the issues in social relations. Historically they were analyzed through categories such as mergers, acquisitions, and strategic alliances, but the emergence of what some call the post-bureaucracy organization or the network organization appears to have given a new meaning to this issue. As a topic of research, this relationship mode shifts the subject of inter-organizational power relations from legal forms of property and contracts to the negotiation of the organization's regulatory boundaries. Organizations positioned poorly in this relationship of power witness the invasion of the boundaries of their service company, as in the cases studied in this research, while others safeguard their boundaries better (Swart and Kinnie, 2003), in accordance with our context sensitive definition of actors and IR systems.

These observations do not necessarily mean that the client is usually or frequently an actor in the IR system. The eventual standardization of products 
offered by B2BTS companies in a context of supplier oligopolization might allow them to reverse this inter-organizational power relationship and open up new ways to regulate labour relations.

This case study, and the other studies that used Bellemare's (2000) analytical framework of the IR actor, confirm the need to develop a new theory of labour relations within a dynamic rather than a static framework that has varying geometries. The various attempts to escape Fordist (or Keynesian) regulation in an era of increasing globalization are an incentive to observe the transformation of the boundaries of the IR system.

The results presented here about emergent modes of regulation suggest that there is a need for future research to further explores the issue of the various space-time contexts of the regulation of work, which are sometimes complementary and sometimes in opposition, and also to look at modes of regulation. Some of our results show that formal legal regulations are not necessarily the most important and that other modes of regulation, for example, those that are based on reputation, may be very effective.

\section{REFERENCES}

Аввотт, Brian. 2006. "Determining the Significance of the Citizens' Advice Bureau as an Industrial Relations Actor." Employee Relations, 28 (5), 435-448.

Alvesson, Mats. 1995. Management of Knowledge-Intensive Companies. Berlin: Walter de Gruyter.

Alvesson, Mats. 2000. "Social Identity and the Problem of Loyalty in Knowledge-Intensive Companies." Journal of Management Studies, 37 (8), $1101-1123$.

Anderson-Gough, Fiona, Christopher Grey and Keith Robson. 2000. "In the Name of the Client: The Service Ethic in Two Professional Services Firms." Human Relations, 53 (9), 1151-1174.

ARTHUR, Michael B. and Denise M. Rousseau. 1996. The Boundaryless Career. A New Employment Principle for a New Organizational Era. Oxford: Oxford University Press.

BAILYN, Lotte. 1993. Breaking the Mold. Women, Men, and Time in the New Corporate World. New York: Free Press.

BaLDACChINo, Godfrey. 2001. "But What Exactly the Directive Say? The Role of EU Experts in Industrial Relations." European Journal of Industrial Relations, 7 (2), 137-152.

Bell, Emma. 2006. "Whose Side Are They On? Patterns of Religious Resource Mobilization in British Industrial Mission." Management and Organizational History, 1 (4), 331-347.

BeLLEMARE, Guy. 2000. "End Users: Actors in the Industrial Relations System?" British Journal of Industrial Relations, 38 (3), 383-405. 
Bellemare, Guy and Regis AcKeYI. 1999. "L'action de la Banque mondiale et du FMI en faveur de la déréglementation des relations du travail dans les pays en voie de développement: le cas du Gabon." Sélection de textes du XXXVI ${ }^{e}$ Congrès de l'Association canadienne des relations industrielles. Québec: ACRI, 153-167.

Bellemare, Guy and Louise BRIAND. 2006. "Transformations du travail/ transformations des frontières des systèmes de relations industrielles." Cahiers du CRISES, $\mathrm{n}^{\circ}$ ET0606. Montréal: CRISES, 1-35.

BENDIX, Robert. 1974. Work and Authority in Industry. Los Angeles: University of California Press.

BERRIBI-HOFFMAN, Isabelle. 2002. "Nouvelle économie, nouveaux pouvoirs?" Sciences Humaines, 125, 32-36.

BHASKAR, Rajnish. 1975. A Realist Theory of Science. Brighton: Harvester.

BJIR (BRITISH JoURNAL OF INDUSTRIAL RELATIONS). 2006. "Special Issue: New actors in Industrial Relations." 44 (4).

BRIAND, Louise and Guy Bellemare. 2005. "A Structurationnist Analysis of Organisational Forms of Firms in the Knowledge Economy." $4^{\text {th }}$ International Critical Management Studies Conference. University of Cambridge, U.K. <http://www.mngt.waikato.ac.nz/ejrot/cmsconference/2005/proceedings/ professions/proceedings_professions.asp $>$.

Briand, Louise and Guy Bellemare. 2006. "A Structurationist Analysis of Post-Bureaucracy in Modernity and Late Modernity." Journal of Organisational Change Management, 19 (1), 65-79.

Briskin, Linda. 2006. Equity Bargaining/Bargaining Equity. Toronto: Centre for Research on Work and Society (CRWS), York University.

Brunelle, Christian. 2002. "L'émergence des associations parallèles dans les rapports collectifs de travail." Relations Industrielles/Industrial Relations, 57 (2), 282-308.

Chasserio, Stéphanie and Marie-Josée Legault. 2005. "Dans la nouvelle économie, la conciliation entre la vie privée et la vie professionnelle passe par... l'augmentation des heures de travail!" Recherches sociographiques, 46 (1), 119-142.

Collins, James. 2006. "Re-Defining the Boundaries of Work: Apparel Workers and Community Unionism in the Global Economy." Identities: Global Studies in Culture and Power, 13 (1), 1-23.

CourPasson, David. 2000. L'action contrainte. Organisations libérales et domination. Paris: PUF.

Coutu, Michel and Gregor Murray. 2005. "La citoyenneté au travail? Une introduction." Relations Industrielles/Industrial Relations, 60 (4), 683-708.

DABSCHECK, Braham. 1994. "A General Theory of (Australian) Industrial Relations." Journal of Industrial Relations, 36 (1), 3-17.

DeFillipPI, Robert J. 2003. "Organizational Models for Collaboration in the New Economy." Human Resource Planning, 25 (4), 7-18. 
Dunlop, John. T. 1958. Industrial Relations Systems. New York: Henry Holt.

EDWARDS, Paul. 2005. "The Challenging but Promising Future of Industrial Relations: Developing Theory and Method in Context-Sensitive Research." British Journal of Industrial Relations, 36 (4), 264-282.

EveTTS, Julia. 1998. "Managing the Technology but not the Organization: Women and Career in Engineering." Women in Management Review, 13 (8), 283-290.

Fleming, Peter and André SpICER. 2004. "You Can Checkout Anytime, but You Can Never Leave': Spatial Boundaries in a High Commitment Organization." Human Relations, 57 (1), 75-94.

Giddens, Anthony. 1984. The Constitution of Society. Cambridge: Polity Press.

Heracleous, Loizos. 2004. "Boundaries in the Study of Organization." Human Relations, 57 (1), 95-103.

Hyman, Richard. 2004. "Is Industrial Relations Theory always Ethnocentric?" Theoretical Perspectives on Work and the Employment Relationship. B. Kaufman, ed. Ithaca: Industrial Relations Research Association Series, 265-292.

JonES, Sandra. 2002. "A Woman's Place is on the Picket Line: Towards a Theory of Community Industrial Relations.” Employee Relations, 24 (2), $151-166$.

Jones, Sandra and Guy Bellemare. 2005. "A Flexible Community Networked Actor Approach.” New Actors in Industrial Relations. Londres: BJIR Workshop, 13 September.

Kochan, Thomas. 2000. "Building a New Social Contract at Work: A Call to Action." Proceedings of the 52 ${ }^{\text {nd }}$ Annual Meeting. Champaign: IRRA series, 1-25.

Kochan, Thomas, Harry KaTZ and Robert MCKersIE. 1986. The Transformation of American Industrial Relations. New York: Basic Books.

Legault, Marie-Josée. 2005a. "Droits de la personne, relations du travail et défis pour les syndicats contemporains." Relations industrielles/Industrial Relations, 60 (4), 683-708.

Legault, Marie-Josée. 2005b. "Differential Gender Effects of Project Management and Management by Project on Skilled Professionals." Sélection de textes du XLI congrès de l'Association canadienne des relations industrielles. K. S. Devine and J.-N. Grenier, eds. Concord: Captus Press, 105-124.

Legault, Marie-Josée and Stéphanie CHASSERIO. 2003. "Family Obligations or Cultural Constraints? Obstacles in the Path of Professional Women." Journal of International Women's Studies (JIWS), 4 (3), <http://www.bridgew.edu/ SoAS/jiws/May03/index.htm>.

Legault, Marie-Josée with the collaboration of Stéphanie ChASSERIO. 2004. Les politiques et les pratiques de conciliation entre la vie professionnelle et la vie privée dans sept organisations de la nouvelle économie de Montréal, 
submitted to the Fonds québécois de recherche sur la société et la culture (FQRSC), <http://www.fqrsc.gouv.qc.ca/recherche/index1.html>.

Legault, Marie-Josée and Hind Belarbi-Basbous. 2006. "Gestion par projets et santé mentale au travail dans la nouvelle économie.” Perspectives interdisciplinaires sur le travail et la santé (PISTES), 8 (1), <www.unites. uqam.ca/pistes $>$.

Michelson, Grant. 2006. "The Role of Workplace Chaplains in Industrial Relations.” British Journal of Industrial Relations, 44 (4), 677-696.

Peltonen, Tuomo. 2006. "The 'Newcomer' MNC and the Re-organization of National Industrial Relations Actor Network." International Journal of Human Resource Management, 17 (9), 1591-1605.

Perlow, Leslie A. 1999. "The Time Famine: Toward a Sociology of Work Time." Administrative Science Quarterly, 44, 57-81.

PIORE, Michael J. 1995. Beyond Individualism. Cambridge: Harvard University Press.

REYNAUD, Jean-Daniel. 1988. "Les régulations dans les organisations: régulation de contrôle et régulation autonome." Revue française de sociologie, 29 (1), $5-18$.

RoBertson, Maxime and Jackie Swan. 2003. "Control, What Control? Culture and Ambiguïty within a Knowledge Intensive Firm." Journal of Management Studies, 40 (4), 831-858.

SAYLES, Robert. 1958. Behavior of Industrial Workgroups. New York: Wiley $\&$ Sons.

SiMPSON, Ruth. 1998. "Presenteeism, Power and Organizational Change: Long Hours as a Career Barrier and the Impact on the Working Lives of Women Managers." British Journal of Management, 9 (1), 37-50.

Singh, Val and Susan Vinnicombe. 2000. "What Does Commitment Really Means? Views of UK and Swedish Engineering Managers." Personnel Review, 29 (2), 228-258.

Swart, Juan and Nicholas KINNIE. 2003. "Knowledge-Intensive Firms: The Influence of the Client on HR Systems." Human Resource Management Journal, 13 (3), 37-55.

Von Hellens, Liisa A., Sue H. Nielsen and Eileen M. Trauth. 2001. "Breaking and Entering the Male Domain: Women in the IT industry." Proceedings of the 2001 Association for Computing Machinery-Special Interest Group on Computer Personnel Research Conference. Mark Serva, ed. New York: ACM, 116-131.

Walton, Richard E. and Robert B. McKersiE. 1995. Theory of Labour Negotiation. New York: McGraw-Hill. 


\section{RÉSUMÉ}

\section{Enjeux théoriques liés aux acteurs et aux modes de régulation émergents}

Dans le contexte d'une grande transformation de l'économie mondiale, on constate de plus en plus l'inadéquation des efforts de théorisation des relations du travail qui datent du fordisme, notamment du modèle d'analyse systémique (Dunlop, 1958) comme du modèle stratégique (Kochan, Katz et McKersie, 1986), en vertu duquel trois acteurs se partagent exclusivement la scène de l'action, c'est-à-dire les syndicats, les employeurs et l'État, dont les interactions se déroulent essentiellement dans le cadre de l'État-nation.

De ce contexte où émergent de nouveaux acteurs dont le poids n'est pas négligeable en relations du travail, les entreprises de services technologiques aux entreprises fournissent un bon exemple, car elles sont très exposées à la concurrence internationale en concourant à la fois sur un marché du produit et du travail international. De ce fait, on y observe de nouveaux modes de régulation émergents qui, à leur tour, illustrent la nécessité d'intégrer de nouveaux acteurs et de nouveaux enjeux aux modèles théoriques du système de relations industrielles, si on veut rendre compte de sa complexité contemporaine. Pour démontrer la présence d'acteurs tout aussi importants que méconnus dans les relations du travail de ce secteur, les auteurs reprennent la définition de l'acteur en relations industrielles de Bellemare (2000) et ses conséquences sur la définition des frontières des systèmes de relations industrielles.

Une enquête a été menée auprès de 88 professionnels de l'informatique des entreprises de services technologiques aux entreprises, dans une population composée à parts égales d'hommes et de femmes. Elle a permis d'y relever des pratiques de régulation qui non seulement remettent en cause les termes traditionnels de la régulation fordiste qui, hier encore, dominaient les bureaucraties professionnelles où on employait les professionnels de l'informatique, mais encore les frontières traditionnelles du système de relations industrielles selon deux aspects. Le premier aspect concerne les trois acteurs principaux: les employeurs, les travailleurs et l'État, par l'ajout du client et des équipes de travail. Le second a trait à la séparation entre les contextes du système de relations industrielles et ce système lui-même.

Les moyens du client sont nombreux, son action a une portée, une continuité ou constance, ainsi que des résultats indéniables. On ne parle plus de changements obtenus par son action, car c'est un mode d'organisation du travail entier qui émerge sous son influence. Ces résultats sont clairement liés à son action : il commande et on obéit, tant les employés que les équipes, 
les chefs de projet, et la direction qui approuve la teneur des contrats aux conditions posées par le client.

Ce cas, comme celui des usagers du transport en commun urbain documenté par Bellemare (2000), montre que ce qui aurait traditionnellement été considéré comme une variable exogène du contexte du système de relations industrielles doit parfois être analysé comme l'émergence de nouveaux acteurs en relations industrielles et que le système, au lieu d'être déterminé par un marché exogène est en fait pénétré de l'intérieur par celui-ci dans certaines situations. Par leur action, ces acteurs influent tant directement qu'indirectement les rapports sociaux du travail.

Ce cas illustre aussi que les rapports interentreprises sont l'un des enjeux de ces rapports sociaux. Historiquement, ces rapports interentreprises s'analysaient avec des catégories telles que les fusions, les acquisitions, les alliances stratégiques, etc. Le développement de ce que certains appellent l'entreprise post-bureaucratique ou l'entreprise en réseau semble poser en termes nouveaux la question des relations interentreprises. À titre de piste de recherche, ce mode de relation déplace l'objet des rapports de force interentreprises des formes juridiques de propriété et de contrats aux négociations des frontières sociales, ou informelles, des entreprises. Certaines, mal placées dans cette relation de pouvoir, voient envahir les frontières de leur entreprise prestataire de service, comme dans les cas étudiés ici, alors que d'autres préservent mieux les leurs. L'enjeu ici est la réduction des coûts ou une plus grande protection contre les risques de la relation contractuelle dans le cadre de produits et services peu uniformisés a priori. 